likely as pregnancy can occur after liver transplantation. ${ }^{3}$ We therefore did not perform a hysterectomy for the menorrhagia.

The patient's negative family history and the donor's negative history negate a genetic basis for cholestasis associated with pregnancy or sex hormones. Rejection of a transplant and cyclosporin, however, can induce low grade cholestasis. Oestrogen may have elicited such an underlying defect much as it can unmask primary biliary cirrhosis that first presents as cholestasis (pruritus) during pregnancy. ${ }^{+}$Thus after liver trans- plantation perhaps primed by treatment with cyclosporin oestrogen may elicit cholestasis.

1 Stone BG, Udani AS, Warty V, Plocki K, Bedetti CD, Van Thiel DH. Cyclosporin A-induced cholestasis: the mechanism in a rat model. Gastroem terologv 1987:93:344-51.

2 Shaffe EA. The liver and pregnancy: update. Current Problems in Obstetrics, Gynecology and Fertility 1987;10:439-501.

3 Walcott WO, Derick DE, Jolley JJ, Snyder DL, Schmid R. Successful pregnancy in a liver transplant patient. Am f Obstel Gynecol 1978;132:340-1. 4 Sherlock S. Primary biliary cirrhosis. In: Schiff L, Schiff ER, eds. Diseases of the liver. Philadelphia: Lippincott, 1987:979-99.

(Accepted 2 August 1989)

\section{Bronchodilator effect of atrial natriuretic peptide in asthma}

\author{
G Hulks, A Jardine, J M C Connell, \\ N C Thomson
}

Department of Respiratory Medicine, Western Infirmary, Glasgow G11 6NT

G Hulks, MRCP, research registrar

N C Thomson, $M D$, consultant physician

Medical Research Council Blood Pressure Unit,

Western Infirmary,

Glasgow

A Jardine, MRCP, research

registrar

J M C Connell, MD,

consultant physician

Correspondence to: $\mathrm{Dr}$ Hulks.

Br Med $\mathcal{F}$ 1989;299:1081-2 bronchomotor tone in asthmatic subjects.

\section{Subjects, methods, and results}

Atrial natriuretic peptide relaxes vascular smooth muscle directly, but little interest has been expressed in its effect on airway smooth muscle despite an in vitro study showing a dose dependent relaxant effect on guinea pig trachea.' This effect has since been observed on tone induced by agonists in vitro, ${ }^{2}$ and a recent in vivo study showed that infusions of atrial natriuretic peptide increased basal airway conductance and reversed bronchoconstriction induced by leukotriene $\mathrm{D}_{4}$ in the same animal model. ${ }^{3}$ We examined the effect of infused atrial natriuretic peptide on

We studied eight subjects (two women; mean (SD) age $39.7(8 \cdot 8)$ years). Each had moderately severe asthma: mean forced expiratory volume in one second was $47 \cdot 2(9 \cdot 8) \%$ of the predicted value and was improved in each subject by $>25 \%$ by inhaled salbutamol. Inhaled bronchodilator agents were withheld for 10 hours, but other inhaled treatment was continued as usual. Written informed consent was obtained and the study approved by Glasgow West ethical committee.

On each of two study days an indwelling venous cannula was inserted into each forearm and the subject relaxed for 20 minutes. We then measured forced expiratory volume in one second (taken as the best of three attempts) with a dry wedge spirometer (Vitalograph) and blood pressure and pulse rate with a semiautomatic sphygmomanometer; we withdrew $20 \mathrm{ml}$ blood to estimate plasma atrial natriuretic peptide concentration by radioimmunoassay ${ }^{4}$ and catecholamine concentrations. After these baseline measurements an intravenous infusion of either atrial natriuretic peptide or placebo was administered in a double blind, randomised manner. Doses of peptide corresponded to $0.5,2 \cdot 0$, and $10.0 \mathrm{pmol} / \mathrm{kg} / \mathrm{min}$ and were given for 20 minutes each in incremental fashion. At the end of each infusion period forced expiratory volume in one second, pulse, blood pressure, and atrial natriuretic peptide and catecholamine concentrations were measured. After the last dose had been completed the infusion was stopped and each subject received $5 \mathrm{mg}$ nebulised salbutamol; final measurements were taken 20 minutes thereafter. The significance of the data was assessed by two way analysis of variance.

The forced expiratory volume in one second rose significantly at the highest rate of infusion with a mean increase of 0.50 ( $95 \%$ confidence interval 0.23 to $0 \cdot 78)$ litre (equivalent to $31.5(14.9$ to $48 \cdot 1) \%$ ) from the baseline value $(p<0.01$; figure). It tended to rise at an

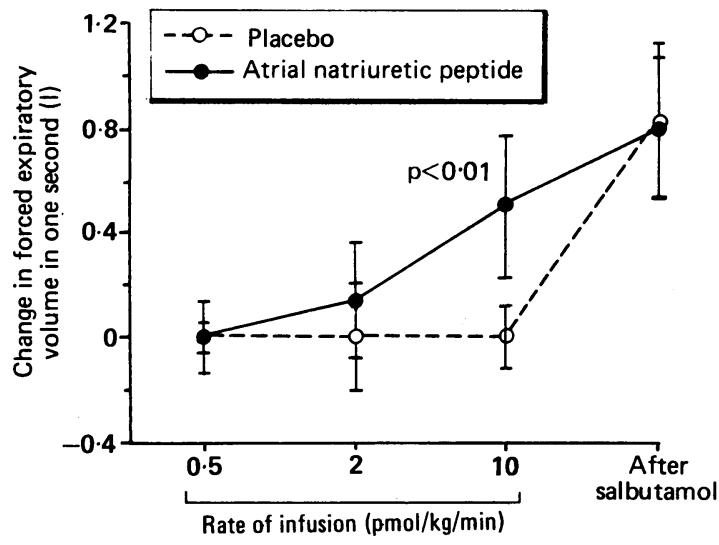

Mean change in forced expiratory volume in one second with varying rates of intravenous infusion of atrial natriuretic peptide compared with placebo $(n=8)$. Nebulised salbutamol $(5 \mathrm{mg})$ was given after final infusion. Vertical bars represent $95 \%$ confidence intervals

infusion rate of $2 \mathrm{pmol} / \mathrm{kg} / \mathrm{min}$, but this was not significant. Overall, the response varied considerably: some subjects responded appreciably to the middle infusion dose while one subject did not respond at all even to the highest dose. No side effects were reported during the active and placebo studies. The mean plasma atrial natriuretic peptide concentration was 10 (95\% confidence interval 6 to 15 ) $\mathrm{nmol} / \mathrm{l}$ basally (normal $2-17 \mathrm{nmol} / \mathrm{l}$ ); this rose to 12 (8 to 16$) \mathrm{nmol} / 1,43$ (33 to 53 ) nmol/l, and 252 (220 to 285 ) nmol// with increasing rates of infusion and had fallen to 12 (11 to 18) $\mathrm{nmol} / \mathrm{l} 20$ minutes after salbutamol.

Baseline pulse, blood pressure, and catecholamine concentrations were comparable, and variation in these measurements between the two study days was not significant.

\section{Comment}

We believe this to be the first report of the effects of atrial natriuretic peptide in asthmatic subjects; we found that it had considerable bronchodilator properties. In many tissues atrial natriuretic peptide alters intracellular events through generating cyclic guanosine monophosphate, and preliminary evidence suggests that a similar action occurs in tracheal smooth muscle. ${ }^{5}$ Although specific receptors have been identified in pulmonary tissue, they have not so far been found in airway smooth muscle. In lung disease atrial natriuretic peptide has been assumed to act as a pulmonary vasodilator in addition to having peripheral renal and vascular action. Our findings suggest that important effects on airway tone may also occur; further studies to explore the peptide's role in pulmonary physiology and disorders of airway tone are indicated.

1 O'Donnell M, Garippa R, Welton AF. Relaxant effect of atriopeptins in isolated guinea-pig airway and vascular smooth muscle. Peptides 1985;6:597-601. 2 Hamel R, Ford-Hutchinson AW. Relaxant profile of synthetic atrial natriuretic factor on guinea-pig pulmonary tissues. Eur $\mathcal{F}$ Pharmacol 1986;121:151-5. 3 Englebach IM, Lappe RW, Hand JM. Bronchoprotective and bronchodilator 
5 Watanabe H, Furui H, Yamaki K, Suzuki R, Takagi T, Satake T. Atria natriuretic peptide causes dose-dependent relaxant effect on guinea-pig tracheal smooth muscle. Am Rev Respir Dis 1988;137:102.

(Accepted I August 1989)

\title{
Managing drug dealers who swallow the evidence
}

\author{
B Marc, R K Gherardi, F J Baud, M Garnier, \\ O Diamant-Berger
}

\section{Forensic Emergencies Department, Hôtel-Dieu de Paris, 1 place du Parvis Notre Dame, 75004 Paris, France \\ B Marc, MD, physician M Garnier, MD, physician O Diamant-Berger, $M D$, physician in charge}

Forensic Medicine Unit, Department of Pathology, Henri Mondor Hospital, 94010 Créteil, France

Toxicologic Intensive Care Unit, Fernand Widal Hospital, Paris VII University, 75010 Paris, France

F J Baud, MD, physician

Correspondence to: Dr Marc.

BrMed f 1989;299:1082
R K Gherardi, MD, physician

Drugs that are concealed by dealers or "body packers" in the gastrointestinal tract for smuggling can be detected by several methods. ${ }^{1-3}$ Analysis of urine, ${ }^{2}$ radiography of the abdomen,,$^{13}$ and natural clearance ${ }^{1-3}$ have been reported. Little has been reported on managing dealers who quickly swallow packets of drugs at the time of arrest ${ }^{3-5}$ apart from an occasional fatal overdose. ${ }^{5}$ Unlike those swallowed by body packers, the drugs ingested by "quick swallowers" are not in wrappings designed for ingestion.

We evaluated the usual methods of drug detection in 50 subjects who were suspected of quick swallowing of drugs and we also gave them an emetic.

\section{Subjects, methods, and results}

Sixty five subjects were referred to the forensic emergencies department in 1988 on suspicion of having swallowed packets of drugs up to two hours before admission. Fifty accepted both a urine analysis and an oral emetic drug. A urine sample was analysed on admission as previously described. ${ }^{2}$ A dose of $15 \mathrm{ml}$ ipecacuanha syrup was given with $200 \mathrm{ml}$ water and repeated once if necessary. In 20 of the 50 subjects supine plain abdominal films were taken to try to detect foreign bodies. Quick swallowing of drugs was considered proved when wrappings or packages were recovered in emesis. The results of drug detection by urine analysis and by abdominal radiography were categorised as follows: $(a)$ positive-positive urine result and wrappings recovered; $(b)$ false positivepositive urine result and no wrappings recovered; (c) false negative-negative urine result and wrappings recovered; $(d)$ negative - negative urine results and no wrappings recovered. The accuracy of both tests was estimated by the sensitivity $(a /(a+c))$, specificity $(d /(b+d))$, and percentage of correct classifications $((a+d)$ divided by number of results).

All but three subjects were conscious and their

Results of drug detection in urine samples and in abdominal radiographs in concealment by quick swallowing (figures are numbers of subjects)

\begin{tabular}{|c|c|c|c|}
\hline \multirow[b]{2}{*}{ Detection of drug } & \multicolumn{2}{|c|}{ Results of emesis } & \multirow[b]{2}{*}{ Analysis of results (\%) } \\
\hline & Recovery of packets & No recovery of packets & \\
\hline \multicolumn{4}{|l|}{ In urine sample: } \\
\hline Positive $^{\star}$ & 16 & 15 & $\begin{array}{l}\text { Sensitivity } 76 \\
\text { Specificity } 42\end{array}$ \\
\hline $\begin{array}{l}\text { Negative } \\
\text { In abdominal radiograph: }\end{array}$ & 5 & 11 & Correct classification 57 \\
\hline Positive & 2 & 2 & $\begin{array}{l}\text { Sensitivity } 33 \\
\text { Specificity } 86\end{array}$ \\
\hline Negative & 4 & 12 & Correct classification 70 \\
\hline
\end{tabular}

* Results included 25 positive for opiates, one for benzoylecgonine (the main urinary metabolite of cocaine), and five for both drugs. cardiorespiratory signs normal. One of the three presented with an isolated transient bradycardia, one in a state of drowsiness, and one with delayed overt heroin overdose. Eight had contracted pupils and two had reactive dilatation of the pupils. In 14 electrocardiographic findings were normal. Emesis occurred within 30 minutes of taking ipecacuanha in 47 of the 50 subjects. Wrappings were recovered after emesis in 21 of those, 19 of whom had swallowed heroin only, and two of whom had swallowed heroin and cocaine. From one to 13 packets were recovered (mean of three). They were of two types: (a) single doses wrapped in paper or aluminium foil containing $250 \mathrm{mg}$ heroin or $1 \mathrm{~g}$ cocaine of the type sold on the street ( 16 of 21 subjects); $(b)$ heroin in packets of one to four single doses, wrapped in a piece of heat sealed plastic dustbin bag (five of 21). The table gives the results of drug detection in urine and in abdominal $x$ ray film. No drug was detected in the urine of subjects who vomited type $(b)$ packets. Radiological images of the packets were usually poorly defined.

\section{Comment}

Ten of 50 subjects had evidence of toxicity from ingesting drugs $-a$ higher incidence than in cases of body packing of packets that are made to be ingested. The methods of managing drug ingestion in body packers are unsuitable for dealers who quick swallow their drugs because drug concentrations were not consistently detected in urine samples-a sensitive but non-specific test-and the images on radiographs were not distinct. Subjects who conceal drugs by swallowing require quick evacuation of gastric contents to avert toxicity. We tried using a stomach tube, but most subjects did not comply, whereas they usually accepted induced emesis. As performed in alert subjects, this seemed to be safe, and packets or wrappings were retrieved in half of the suspected subjects. and treatment. IAMA 1983;250:1417-20.

Gherardi RK, Baud FJ, Leporc P, Marc B, Dupevron JP, Diamant-Berger O. Detection of drugs in the urine of body-packers. Lancet 1988;i:1076-8.

3 Marc B, Gherardi R, Baud FJ, Diamant-Berger O. The spectrum of in-body drug concealment: diagnosis and emergency treatment. European foumal of Emergencies 1989;2:81-7.

4 Robins JB, Rae PW. Recovery of heroin ingested packets. Arch Emerg Med 1986;2:125-7.

5 Goldfrank FR Cocaine. In: Goldfrank FR, Flomembaum NE, Lewin NA Weisman RS, Howland MA, Kulberg AG, eds. Toxicologic emergencies. 3rd ed. Norwalk, Connecticut: Appleton Century Crofts, 1986:477-85.

(Accepted 14 fuly 1989)

\section{Correction}

Influence of past reproductive performance on risk of spontaneous abortion

Three authors' errors occurred in this paper by Dr Lesley Regan and others (26 August, p 541). The numbers in the bottom line of table III (primigravida) should have read 3, 54, and 6, not 13, 154, and 16 as published. 